\title{
In-vitro Evaluation of Antioxidant Activity and Anti-collagenase Activity of Thalassia hempricii as a Potent Ingredients for Anti-Wrinkle Cosmetics
}

\author{
Kiki Zakiah ${ }^{1}$, Effionora Anwar ${ }^{2 *}$, Tati Nurhayati ${ }^{3}$
}

Kiki Zakiah', Effionora Anwar $^{2^{*}}$, Tati Nurhayati ${ }^{3}$

'Master student at Faculty of Pharmacy, Universitas Indonesia, Depok, INDONESIA.

${ }^{2}$ Professor at Department of Pharmacy Technology, Faculty of Pharmacy, Universitas Indonesia, Depok, INDONESIA.

${ }^{3}$ Doctor, Faculty of Fisheries and Marine Sciences, Bogor Agricultural University, Bogor, INDONESIA.

Correspondence

Prof. Effionora Anwar

Faculty of Pharmacy, Universitas Indonesia, Kampus UI Depok, 16424,

West Java, INDONESIA.

Phone no : +62-21-7270031

E-mail: effionora.anwar@farmasi.ui.ac.id

History

- Submission Date: 27-11-2017

- Review completed: 14-02-2018;

- Accepted Date: 19-02-2018

DOI : 10.5530/pj.2018.4.131

Article Available online

http://www.phcogj.com/v10/i4

Copyright

(C) 2018 Phcog.Net. This is an openaccess article distributed under the terms of the Creative Commons Attribution 4.0 International license.

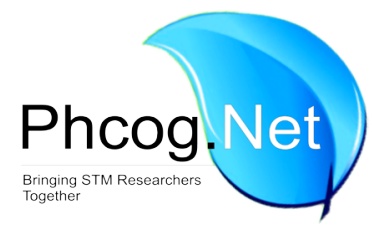

\begin{abstract}
Background: Thalassia hemprichii have reported containing antioxidant effects. However, information on other biological activities relating to the anti-wrinkle properties is limited. The free radical scavenging activity and enzyme inhibitory activity of the plant extracts investigated that they can help restore skin elasticity and thereby slow the wrinkling process. Objective: To evaluate in-vitro antioxidant and anti-collagenase activity of $T$. hemprichii as a potent ingredient for anti-wrinkle cosmetic. Methods: T. hemprichii was extracted with ethanol 100\% (E1) $75 \%$ (E2) and ethanol 50\% (E3) using maceration extraction method for $24 \mathrm{~h}$, thrice. The extract was examined for total phenolic content, antioxidant activity compared with vitamin $\mathrm{C}$, and the best extract was tested for the inhibitory activity of collagenase. Results: The total phenolic content of $T$. hempricii extract was 0,525 $\pm 0,016 \mathrm{mg} \mathrm{GAE} / 100 \mathrm{~g}$ extract (E1) 0,538 \pm $0,006 \mathrm{mg} \mathrm{GAE} / 100 \mathrm{~g}$ extract (E2) and 0,558 $\pm 0,090 \mathrm{mg} \mathrm{GAE} / 100 \mathrm{~g}$ extract (E3) respectively. The antioxidant activity (\% inhibition) of the extract was 38,035 $\pm 0,252 \%$ (E1), 52,502 \pm $6,225 \%$ (E2) and 57,261 $\pm 0,505 \%$ (E3). Ascorbic acid as a positive control of antioxidant activity showed much higher $\%$ inhibition than the sample with $78,055 \pm 0,756 \%$. As the best extract from antioxidant activity, E2 and E3 have inhibited collagenase activity with $51,809 \pm 0,164 \%$ and $52,212 \pm 0,735 \%$ at $20 \mu \mathrm{g} / \mathrm{mL}$ respectively. Conclusion: In general the ( $T$. hempricii) extract can be used as a potential active ingradient for anti-wrinkles cosmetic.

Key words: Thalassia hempricii, Seagrass, Antioxidant, Collagenase, Anti-wrinkle.
\end{abstract}

\section{INTRODUCTION}

Wrinkle, as a manifestation of skin aging, is a natural process that will be experienced by every living creature. But the aging process of each person is not the same, because it is influenced by several factors, both extrinsic and intrinsic. Extrinsic factor such as environmental exposure like sunlight recurring to the skin causing sunburn and dry skin or wrinkle. The intrinsic such as genetics, hormonal changes, metabolic processes factor. ${ }^{1}$ Skin repeatedly exposed to ultraviolet light is made up of two type of harmfull ray that penetrate deep into the dermis, so cause physical changes and finally generated Reactive Oxigen Scavenger (ROS). ROS cause damage lipid, protein and DNA of the skin. ${ }^{2}$ ROS indirectly induce production of MMPs via MAP- kinase pathway. ${ }^{3}$ Like all other organs, undergoes chronological aging. In addition, unlike other organs, skin is in direct contact with the environment and therefore undergoes aging as a consequence of environmental damage. The primary environmental factor that causes human skin aging is UV irradiation from the sun. This sun-induced skin aging (photoaging MMPs are a group of zinc-dependent extracellular proteinases divided into five sub-groups based on their substrate such as collagenase. Collagenase is responsible

for extracellular matrix (ECM) cause of collagen breakdown. Elastase is serine proteinase that responsible for the breakdown of elastin in ECM. When collagen and elastin always maintain the skin structural integrity and elasticity, collagen and elastin contribute to undesired wrinkles. Plant extracts usually content phenol, polyphenol, flavonoid they possess antioxidant activity, that used as anticollagenase and anti-elastase activities. ${ }^{4}$ several studies have reported investigations on plant extracts as inhibitors of proteinases and as anti-oxidants. The anti-ageing and anti-oxidant properties of 23 plant extracts (from 21 plant species

The activity of the potential antioxidants to prevent skin damage cause by ROS. Previous study have revealed that seagrass polyphenols has antioxidant activity. ${ }^{5}$ Seagrass also reported has a richer sources of natural antioxidant than seaweeds. ${ }^{6}$ Other study reported that Thalassia hempricii, one of Indonesian seagrass species, has $\mathrm{IC}_{50}$ values $123.72 \pm 9.99 . .^{5}$

Nowadays, research on marine plants has been done a lot, to get more information and evidence. However, research on the inhibition of enzymes by sea-

Cite this article: Zakiah K, Anwar E, Nurhayati T. In-vitro Evaluation of Antioxidant Activity and Anti-collagenase Activity of Thalassia hempricii as a Potent Ingredients for Anti-Wrinkle Cosmetics. Pharmacog J. 2018;10(4):778-82. 
grass is limited. Therefore, this study aims to test the phenolic content, the capacity of antioxidant and inhibitory activity of collagenase enzyme from Thalassia hemprichii extract. Inhibition of collagenase activities by natural plant compounds might be a promising approach to prevent extrinsic skin aging like a wrinkle.

\section{MATERIALS AND METHODS}

\section{Material}

Thalassia hemprichii obtained from Pasauran Beach, Serang, Banten, West Java-Indonesia, 2,2-Diphenyl-1-picrylhydrazyl (DPPH), Gallic acid, Ascorbic acid, C. histolyticum collagenase (ChC) (type IA), N-[3-(2-furyl) acryloyl]-Leu-Gly-Pro-Ala (FALGPA) and Epigallocatechingallate ( $\geq 95 \%$ ) were purchased from Sigma-Aldrich. $\mathrm{FeCl}_{3}$, FolinCiocalteu reagent, and Sodium carbonate were purchased from Merck.

\section{Methods}

\section{Preparation of seagrass extract}

After collected from Binuangeun Beach, Banten, Indonesia. T. hemprichii leaves and rhizome were washed immediately using sea water to remove sand particles, and maintained with ice box throughout the expedition. Then T. hempricii rinsed several times, dried and stored. Next, T. hempricii was conducted determination at Biology Center of Indonesian Institute of Sciences (LIPI) to ensure the species.

To get the extract, dried leaves and root were extracted using maceration method for $24 \mathrm{~h}$ in $100 \%, 75 \%$ and $50 \%$ with ethanol at room temperature under dark condition. Then the mixture was centrifuged (5000 rpm for $10 \mathrm{~min}$ ) to separate the residue and filtrate. The filtrate was evaporated using a rotary vacuum evaporator (Buchi, Switzerland).

\section{Phytochemical Screening of Thalassia hempricii}

Qualitative analysis of the T. hempricii extract determined by Meyer and Dragendorff reagents for alkaloid, ferric chloride test for phenol, magnesium turning test for flavonoids and $\mathrm{FeCl}_{3}$ for tannins according to previous study. ${ }^{7}$

\section{Total Phenolic Content (TPC) of T. hempricii extract}

Total phenols was measured by the modified Folin-Ciocalteu method. ${ }^{8}$ such as treatment of fever, skin diseases, muscle pains, wounds and stomach problems. Hence it is essential to study their bioactive metabolites and medicinal properties when considering their food applications. In the present study, the leaves of six seagrasses Enhalus acoroides, Thalassia hemprichii, Halodule pinifolia, Syringodium isoetifolium, Cymodocea serrulata and Cymodocea rotundata were extracted with aqueous methanol and tested for their antioxidant capacity. Among them, H. pinifolia recorded high phenolic (21.64 mg g-1 using a Shimadzu UV-VIS spectrophotometer (UV-2450). 0, $5 \mathrm{ml}$ extract was mixed with $1 \mathrm{~mL}$ of $10 \%$ Folin-ciocalteu reagent $(1: 10 \mathrm{v} / \mathrm{v})$ and $2 \mathrm{~mL}$ $(75 \mathrm{~g} / \mathrm{L})$ of sodium carbonate. The tubes were homogenized by vortex for $15 \mathrm{sec}$ and allowed to stand for $30 \mathrm{~min}$ for the reaction. Absorbance was then measured at $720 \mathrm{~nm}$ using UV-VIS Spectrophotometer. The calibration curve was prepared by putting the value of absorbance vs. concentration. ${ }^{9}$ The total phenolic content was expressed as Gallic Acid Equivalent (GAE) in milligram per $100 \mathrm{~g}$ dried extract. ${ }^{5}$

\section{Antioxidant activity of T. hempricii extract}

Free radical scavenging activity was determined by Molyneux method. ${ }^{10}$ with slight modifications. As much as $1.0 \mathrm{~mL}$ of sample was added to 3.0 $\mathrm{mL}$ of $40 \mathrm{ppm} \mathrm{DPPH}$ solution. In the dark condition, the mixture was homogenized by vortex for about $20 \mathrm{sec}$, then kept at room temperature for $30 \mathrm{~min}$, and the absorbance was measured at $517 \mathrm{~nm}$. Ascorbic acid was used as positive control. Antioxidant activity of T. hempricii was expressed as percentage of DPPH scavenging effect (\%). The scavenging effect of DPPH radicals was calculated using the equation:

$$
\text { DPPH Scavenging effect }(\%)=1-\frac{\mathrm{A}_{0}-\mathrm{A}_{1}}{\mathrm{~A}_{0}} \times 100
$$

Note: $A_{0}$ is the absorbance of the control, $A_{1}$ is the absorbance of the sample.

\section{Anti-Collagenase Activity of T. hempricii extract}

Inhibitory activity of Thalassia hempricii extract against $C$. histolyticum collagenase (ChC) was measured using spectrophotometry microplate reader by Wittanauer methods. ${ }^{11}$ with slight modification. $50 \mu$ ltricine buffer solution ( $\mathrm{pH} 7.5$ ), $50 \mu \mathrm{l}$ of sample and $50 \mu \mathrm{l}$ of enzyme (125 Unit/ml ChC, type IA) were added into 96-well microplate. Then $50 \mu$ FALGPA $(0.5 \mathrm{mM})$ was added to start the reaction. The solution was then incubated for $15 \mathrm{~min}$. The ChC inhibitory activities of the individual samples were measured by continuously monitoring the decrease in absorbance of FALGPA and expressed as percentage inhibition (\%). The relative inhibition was calculated according to Equation below:

$$
\text { Percentage inhibition }(\%)=1-\frac{\mathrm{Os}}{\mathrm{Oc}} \times 100
$$

Note: $\mathrm{O}_{\mathrm{s}}$ is the corrected absorbance enzyme in the presence of samples, $\mathrm{O}_{\mathrm{c}}$ is the corrected absorbance of enzyme without samples.

\section{RESULTS}

Phytochemical Screening

Sample that we used in this study is true Thalassia hempricii, base on determination at The Biology Center of Indonesian Institute of Sciences (LIPI). We found that phytochemical qualitative analysis chemical substances of $100 \%$ (E1), $75 \%$ (E2) and $50 \%$ (E3) ethanolic extract of all parts of the plants (roots and leaves), showed that T. hempricii contained alkaloids, flavonoids, phenols and tannins (Table 1).

\section{Total Phenolic Content (TPC) of T. hempricii extract}

A calibration curve of Gallic acid (ranging from 100 to $700 \mu \mathrm{g}$ ) was prepared and the total phenolic content was standardized against gallic acid and is expressed as $\mathrm{mg}$ Gallic acid equivalents per $100 \mathrm{~g}$ of sample on a dry weight basis. $R^{2}=0,9903, y=0,0007 x-0,0853$. Total phenol in the extract of $T$. hempricii was $0,525 \pm 0,016 \mathrm{mg} \mathrm{GAE} / 100 \mathrm{~g}$ extract (E1) $0,538 \pm 0,006 \mathrm{mg} \mathrm{GAE} / 100 \mathrm{~g}$ extract (E2) and 0,558 $\pm 0,090 \mathrm{mg} \mathrm{GAE} / 100 \mathrm{~g}$ extract (E3) respectively (Figure 1). As we can see in Figure 1, Compared to $\mathrm{E} 1$ and E2, E3 contains higher amount of phenol with 0,558 $\pm 0,090$ mg GAE/100 g extract. We can say that E1 $<$ E2 $<$ E3.

\section{Table 1: Qualitative test of phytochemical constituent.}

\begin{tabular}{cccc}
\hline Phytochemical constituents & \multicolumn{3}{c}{ T. hempricii ethanolic extract } \\
\hline & $50 \%$ & $75 \%$ & $100 \%$ \\
\hline Alkaloids & ++ & ++ & ++ \\
Flavanoids & ++ & ++ & + \\
Phenols & ++ & ++ & ++ \\
Tannins & ++ & ++ & + \\
\hline
\end{tabular}

Note : $(++++)$ : very high content; $(+++)$ : high content; $(++)$ : moderate content; $(+)$ : low content; (-) : not detected 


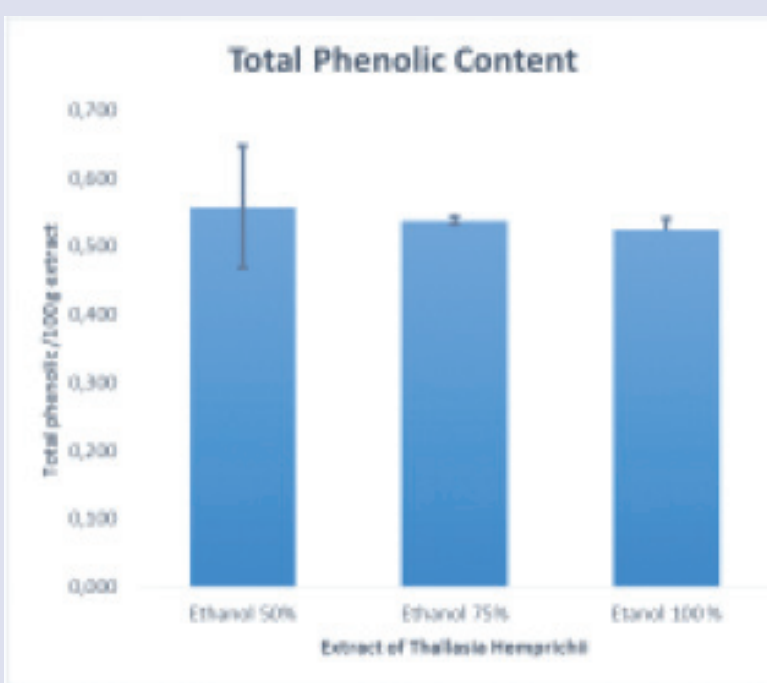

Figure 1: Total Phenolic Content of Thalassia hempricii.

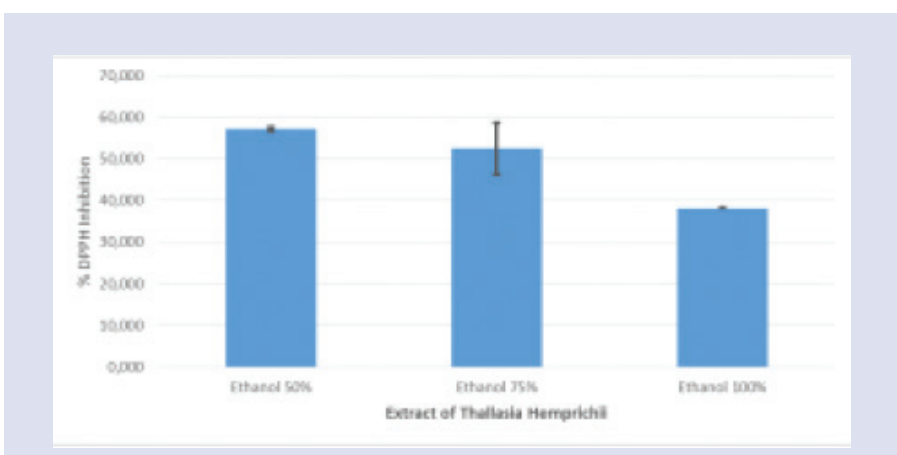

Figure 2: \% DPPH Inhibition of Thalassia hempricii.

\section{Antioxidant activity of $T$. hempricii extract}

In this study, the \% inhibition of T. hempricii extract using DPPH assay was 38,035 $\pm 0,252 \%(\mathrm{E} 1), 52,502 \pm 6,225 \%$ (E2) and 57,261 $\pm 0,505 \%$ (E3). This result are presented in Figure 2. Positive control of ascorbic acid showed much higher \% inhibition than the sample with 78,055 \pm $0,756 \%$. As in the Figure 2, E2 and E3 gives a greater \% inhibitory value, compared to E1.

\section{Anti-Collagenase Activity of T. hempricii extract}

We used microplate reader with spectrophotometry method at wavelength $340 \mathrm{~nm}$ to determine the inhibitory activity of E2 and E3 that showed highest \% antioxidant activity. E3 gives a greater \% inhibitory value, with $52,212 \pm 0,735$ at $20 \mu \mathrm{g} / \mathrm{mL}$, as well as a higher $\%$ inhibition DPPH value compared to E2 which gives $51,809 \pm 0,164 \%$ at $20 \mu \mathrm{g} / \mathrm{mL}$ (Figure 3).

\section{DISCUSSION}

Based on phytochemical screening, data show that the extract contains alkaloid, flavonoid, phenol, and tannin (polyphenol). Alkaloids compounds are discovered can stop free radical chain by donating $\mathrm{H}$ atoms in free radicals. ${ }^{12}$ Ferric reducing ability of plasma and metal chelating assays. Results: Malaria infection caused the formation of free radicals which

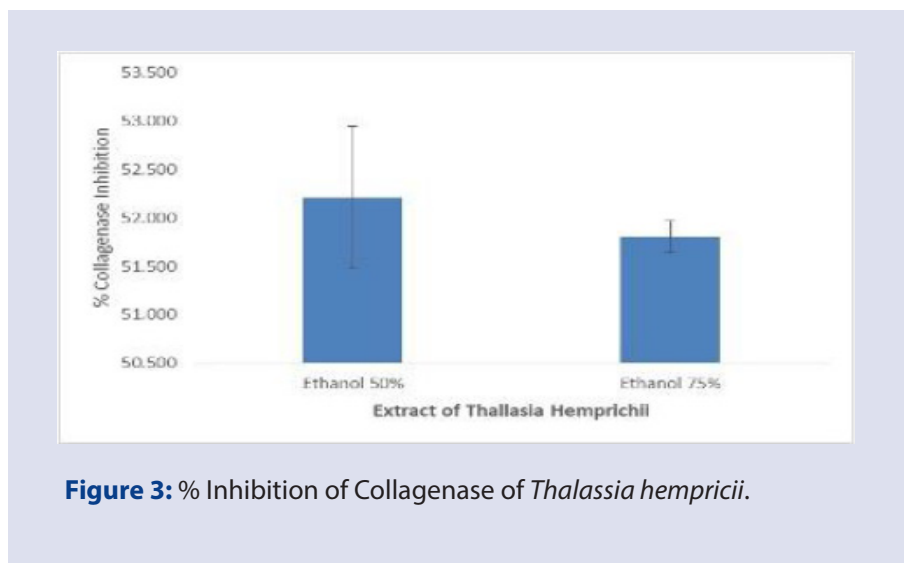

subsequently led to oxidative stress and apoptosis. The antioxidant properties of the alkaloids under investigation revealed that in addition to the antiplasmodial activity, the alkaloids could also prevent oxidative stress. (+ Other study reported that Marine Alkaloids can inhibit MMP-1 (human fibroblast collagenase). ${ }^{13}$ Flavanoids claimed have impact on the antioxidant capacity because $\mathrm{OH}$ group in flavanoid can be used to donate $\mathrm{H}$ atoms in free radicals. The antioxidant activity of flavonoids and their metabolites in vitro depends upon the arrangement of functional groups about the nuclear structure. ${ }^{14}$ Phenolic and flavonoid content are associated with antioxidant activity especially in terms of DPPH and nitric oxide free radical scavenging. ${ }^{15}$ Tannins or polyphenols scavenge free radicals with a complex kinetic that involves quick and slow steps of scavenging. ${ }^{16}$

Seagrasses are rich in proanthocyanidin (condensed tannins) as one of the phenolic compounds. ${ }^{17}$ Phenolic compounds has been reported that against oxidative stress-mediated disorders and have received intense attention as potential therapeutic agents against a wide range of diseases including neurodegenerative diseases, cancer, diabetes, cardiovascular dysfunction, inflammatory diseases as well as aging. ${ }^{18}$ In many cases, phenolic compounds are claimed to be the main active constituent explaining the seagrass antioxidant activity. ${ }^{8,18}$ such as treatment of fever, skin diseases, muscle pains, wounds and stomach problems. Hence it is essential to study their bioactive metabolites and medicinal properties when considering their food applications. In the present study, the leaves of six seagrasses Enhalus acoroides, Thalassia hemprichii, Halodule pinifolia, Syringodium isoetifolium, Cymodocea serrulata and Cymodocea rotundata were extracted with aqueous methanol and tested for their antioxidant capacity. Among them, H. pinifolia recorded high phenolic (21.64 mg g-1).

The pharmacological actions of phenolic antioxidants against free radical scavenging is very important to inhibit wrinkle, because skin which repeatedly exposed to ultraviolet light every day, can occurred wrinkles. ${ }^{19}$ The presence of some phytoconstituents, such as phenols, flavonoids and tannins in seagrasses may be the cause of antioxidant activity in preventing occurred wrinkles or inhibit collagenase activity. ${ }^{20}$

The selection of solvent types is essential for efficiency of the extraction process, because the compound of solvent with different polarity provides different antioxidant potential. ${ }^{21}$ The most widely solvents applied for extraction so far is methanol, ethanol and acetone or mixtures with water can bring up various polyphenols from various phenolic structures. ${ }^{22}$ mainly for quality control purposes. The effects of experimental variables, such as solvent composition and volume and time and temperature on extraction, have been studied. A unique gradient program for the separation of several phenolic classes (hydroquinones, hydroxybenzoic acids, flavan-3-oles, hydroxycinnamic acids, coumarins, flavanones, flavones, 
dihydrochalcones and flavonols The use of water with other organic solvents as a combination contributes to the formation of fairly small polar media ensuring the extraction of polyphenols. ${ }^{23}$ This research choose ethanol-water solvent for making the extract. However, difference state of the seagrass growth site can result difference total content of phenol. ${ }^{24}$ For example, TPC for T. hempricii that was collected from Chinnapallam, Gulf of Mannar Biosphere Reserve, Tamilnadu, India has $2.76 \pm 0.170 \mathrm{mg} \mathrm{GAE} / \mathrm{g}$ sample ${ }^{8}$ such as treatment of fever, skin diseases, muscle pains, wounds and stomach problems. Hence it is essential to study their bioactive metabolites and medicinal properties when considering their food applications. In the present study, the leaves of six seagrasses Enhalus acoroides, Thalassia hemprichii, Halodule pinifolia, Syringodium isoetifolium, Cymodocea serrulata and Cymodocea rotundata were extracted with aqueous methanol and tested for their antioxidant capacity. Among them, H. pinifolia recorded high phenolic (21.64 mg g-1. Meanwhile, T. hempricii that was collected from Palk bay, India has $6 \mathrm{mg} \mathrm{GAE} / \mathrm{g}$ sample. ${ }^{25}$ Environmental conditions have great influences in the antioxidant property and the accumulation of the phytochemicals. ${ }^{26}$ The DPPH assay has been commonly used to measure the free radicalscavenging ability of plants. ${ }^{27}$ The antioxidant effect on DPPH radical scavenging may be due to those ability to donate hydrogen. When the $\mathrm{DPPH}$ solution is mixed with a substrate acting as a hydrogen atom donor, a stable non-radical DPPH formed characterized by a simultaneous change of violet color to pale yellow. ${ }^{10} \mathrm{DPPH}$ assay is most suitable for polar compounds because the DPPH crystals can dissolve easily in a commonly solvent and give maximum absorbance. ${ }^{28}$ Based on Figure 2, E2 and E3 shows greater \% scavenging effect, compared to E1. TPC of T. hempricii related with the antioxidant activity. Other research reported $38.62 \pm 0.62 \%$ for inhibitory activity of DPPH assay of T. hempricii. ${ }^{8}$ such as treatment of fever, skin diseases, muscle pains, wounds and stomach problems. Hence it is essential to study their bioactive metabolites and medicinal properties when considering their food applications. In the present study, the leaves of six seagrasses Enhalus acoroides, Thalassia hemprichii, Halodule pinifolia, Syringodium isoetifolium, Cymodocea serrulata and Cymodocea rotundata were extracted with aqueous methanol and tested for their antioxidantcapacity. Among them, H.pinifolia recorded high phenolic (21.64 mg g-1 The varying antioxidant capacity of various plant extracts can be attributed to differences in chemical composition of plants such as phenolic acids, and flavonoids. ${ }^{8,26}$ such as treatment of fever, skin diseases, muscle pains, wounds and stomach problems. Hence it is essential to study their bioactive metabolites and medicinal properties when considering their food applications. In the present study, the leaves of six seagrasses Enhalus acoroides, Thalassia hemprichii, Halodule pinifolia, Syringodium isoetifolium, Cymodocea serrulata and Cymodocea rotundata were extracted with aqueous methanol and tested for their antioxidant capacity. Among them, $H$. pinifolia recorded high phenolic (21.64 mg g-1

The collagenase inhibition by E3 related with the total phenolic content and antioxidant activity of DPPH. Additionally, Antioxidant activities of plants extracts were correlated with their total phenolic content. ${ }^{29}$ The characteristics of polyphenols may differ, depend on the solvent used during the extraction of the two solvents. ${ }^{23}$ There's can be different mechanism of anti-aging or anti-wrinkle properties on plants extract. ${ }^{27}$ So, E3 might be used as an active ingredient for anti-aging or anti-wrinkle products.

\section{CONCLUSION}

In general, the T. hempricii extract can be used as a potential active ingradient for anti-wrinkles cosmetic.

\section{ACKNOWLEDGEMENT}

The author would like to thank the financial support from DRPM UI Grant of Indexed International Publication of Student Final Project (Publikasi Internasional Terindeks Untuk Tugas Akhir Mahasiswa/ PITTA) 2017.

\section{ABBREVIATIONS}

T. hempricii: Thalassia hempricii; ECM: extracellular matrix; DPPH: 2,2-Diphenyl-1-picrylhydrazyl; ChC: C. histolyticum collagenase; FALGPA: N-[3-(2-furyl) acryloyl]-Leu-Gly-Pro-Ala; GAE: Gallic Acid Equivalent.

\section{CONFLICT OF INTEREST}

The authors declare no conflict of interest.

\section{REFERENCES}

1. Helfrich YR, Sachs DL, Voorhees JJ. Overview of Skin Aging and Photoaging. Dermatology Nurs. 2008;20(3):177-83.

2. Demeule $M$, Brossard $M$, Pagé $M$, Gingras $D$, Béliveau R. Matrix metalloproteinase inhibition by green tea catechins. Biochim Biophys Acta. 2000;1478(1):51-60. doi:10.1016/S0167-4838(00)00009-1.

3. Fisher GJ, Kang S, Varani J, et al. Mechanisms of photoaging and chronological skin aging. Arch Dermatol. 2002;138(11):1462-70. doi:10.1001/archderm. 138.11.1462.

4. Thring TS, Hili $P$, Naughton DP. Anti-collagenase, anti-elastase and anti-oxidant activities of extracts from 21 plants. BMC Complement Altern Med. 2009;9(1):27. doi:10.1186/1472-6882-9-27.

5. Paper O, Santoso J, Anwariyah S, et al. Phenol content, antioxidant activity and fibers profile of four tropical seagrasses from indonesia. J Coast Dev. 2012;15(2):189-96

6. Ramah S, Etwarysing L, Auckloo N. Internet Journal of Medical Update Prophylactic antioxidants and phenolics of seagrass and seaweed species : A seasonal variation study in a Southern Indian Ocean Island, Mauritius. Internet J Med Updat. 2014;9(1):27-37.

7. Harborne JB. Phytochemical Methods A Guide to Modern Techniques of Plant Analysis. London: Chapman and Hall; 1987. doi:10.1007/978-94-009-5921-7.

8. Ragupathi Raja Kannan $R$, Arumugam $R$, Thangaradjou T, Anantharaman P. Phytochemical constituents, antioxidant properties and p-coumaric acid analysis in some seagrasses. Food Res Int. 2013;54(1):1229-36. doi:10.1016/j.foodres 2013.01.027.

9. Kabir MSH, Hossain MM, Kabir MI, et al. Phytochemical screening, Antioxidant Thrombolytic, alpha-amylase inhibition and cytotoxic activities of ethano extract of Steudnera colocasiifolia K. Koch leaves. J Young Pharm. 2016;8(4):391-7. doi:10.5530/jyp.2016.4.15.

10. Molyneux P. The use of the stable free radical diphenylpicryl- hydrazyl ( DPPH) for estimating antioxidant activity. Songklanakarin J Sci Technol. 2004;26(June 2003).

11. Wittenauer J, MäcKle S, Sußmann D, Schweiggert-Weisz U, Carle R. Inhibitory effects of polyphenols from grape pomace extract on collagenase and elastase activity. Fitoterapia. 2015;101:79-187. doi:10.1016/j.fitote.2015.01.005.

12. Zahari A, Ablat A, Sivasothy $Y$, Mohamad J, Choudhary MI, Awang K. In Vitro antiplasmodial and antioxidant activities of bisbenzylisoquinoline alkaloids from Alseodaphne corneri Kosterm. Asian Pac J Trop Med. 2016;9(4):328-32. doi:10.1016/j.apjtm.2016.03.008

13. Farrokhnia M, Mahnam K. Molecular dynamics and docking investigations of several zoanthamine-type marine alkaloids as matrix metaloproteinase-1 inhibitors. Iran J Pharm Res. 2017;16(1):173-86.

14. Heim KE, Tagliaferro AR, Bobilya DJ. Flavonoid antioxidants: Chemistry, metabolism and structure-activity relationships. J Nutr Biochem. 2002;13(10):572-84. doi:10.1016/S0955-2863(02)00208-5.

15. Karimi E, Mehrabanjoubani P, Keshavarzian M, Oskoueian E, Jaafar HZ, Abdolzadeh A. Identification and quantification of phenolic and flavonoid components in straw and seed husk of some rice varieties (Oryza sativa L) and their antioxidant properties. J Sci Food Agric. 2014;94(11):2324-2330. doi:10.1002/jsfa.6567.

16. Riedl KM, Carando S, Alessio HM, Mccarthy M, Hagerman AE. Antioxidant Activity of Tannins and Tannin- Protein Complexes: Assessment in vitro and in vivo. Symp A Q J Mod Foreign Lit. 2002:188-200.

17. Arnold TM, Targett NM. Mini Review Marine Tannins: The Importance of A Mechanistic Framework For Predicting Ecological Roles. J Chem Ecol. 2002;28(10):1919-34. 
18. Soobrattee MA, Neergheen VS, Luximon-ramma A. Phenolics as potential antioxidant therapeutic agents: Mechanism and actions. Mutat Res. 2005;579:200-213. doi:10.1016/j.mrfmmm.2005.03.023.

19. Ichihashi M, Ando H, Yoshida M, NikiY, Matsui M. Photoaging of the skin. AntiAging Med. 2009;6(6):46-59. doi:10.3793/jaam.6.46.

20. Kähkönen MP, Hopia Al, Vuorela HJ, et al. Antioxidant Activity of Plant Extracts Containing Phenolic Compounds. J Agric Food Chem. 1999:47(10):3954-62. doi:10.1021/jf990146l.

21. Aida W. Optimization of extraction conditions for phenolic compounds from neem ( Azadirachta indica ) leaves. Int Food Res J. 2011;18(3):931-9.

22. Abad-García B, Berrueta LA, López-Márquez DM, Crespo-Ferrer I, Gallo B, Vicente F. Optimization and validation of a methodology based on solvent extraction and liquid chromatography for the simultaneous determination of several polyphenolic families in fruit juices. J Chromatogr A. 2007;1154(1-2):87-96 doi:10.1016/j.chroma.2007.03.023.

23. Sonia O, Mohamed C. Optimisation Of Solvent Extraction Of Antioxidants (Phenolic Compounds) From Algerian Mint ( Mentha spicata L .) Optimisation Of Solvent Extraction Of Antioxidants ( Phenolic Compounds) From Algerian Mint ( Mentha spicata L.). Res Gate. 2014;(June). doi:10.5530/pc.2012.4.1.

24. Gokce G, Haznedaroglu MZ. Evaluation of antidiabetic, antioxidant and vasoprotective effects of Posidonia oceanica extract. J Ethnopharmacol. 2008;115(1):122-30. doi:10.1016/j.jep.2007.09.016.

25. Ragupathi R, Kannan R, Arumugam R, Anantharaman P. Chemical composition and antibacterial activity of Indian seagrasses against urinary tract pathogens FOOD Chem. 2012;135(4):2470-3. doi:10.1016/j.foodchem.2012.07.070.

26. Gnanasekaran N, John JR, Sakthivel G, Kalavathy S. The Comparative Studies of the Phytochemical Levels and the in vitro Antioxidant Activity of Tridax procumbens L. from Different Habitats. Free Radicals Antioxidants. 2016;7(1):50-6. doi:10.5530/fra.2017.1.8.

27. Zhang J, Yuan K, Zhou W-L, Zhou J, Yang P. Studies on the active components and antioxidant activities of the extracts of Mimosa pudica Linn. from southern China. Pharmacogn Mag. 2011;7(25):35-9. doi:10.4103/0973-1296.75899.

28. Budiman A, Aulifa DL, Satria A, Kusuma W, Sulastri A, Wira AS. Antibacterial and Antioxidant Activity of Black Mulberry (Morus nigra L.) Extract for Acne Treatment. Pharmacogn J. 2017;9(5):611-4.

29. Ghimeray AK, Jung US, Lee HY, Kim YH, Ryu EK, Chang MS. In vitro antioxidant, collagenase inhibition, and in vivo anti-wrinkle effects of combined formulation containing Punica granatum, Ginkgo biloba, Ficus carica, and Morus alba fruits extract. Clin Cosmet Investig Dermatol. 2015;8:389-96. doi:10.2147/CCID. S80906.

\section{GRAPHICAL ABSTRACT}

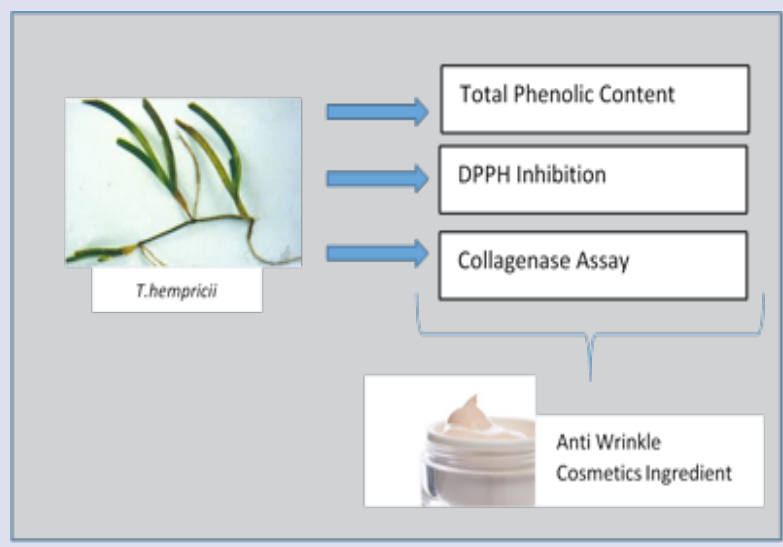

\section{SUMMARY}

- Previous study have revealed that seagrass polyphenols has antioxidant activity. Seagrass also reported has a richer sources of natural antioxidant than seaweeds. Other study reported that Thalassia hempricii, one of Indonesian seagrass species, has potential $I C_{50}$ value.

- Nowadays, research on marine plants has been done a lot, to get more information and evidence. However, research on the inhibition of enzymes by seagrass is limited. Therefore, this study aims to test the inhibitory activity of collagenase enzyme from Thalassia hemprichii extract. Inhibition of collagenase activities by natural plant compounds might be a promising approach to prevent extrinsic skin aging like a wrinkle.

- The present study describe anti-wrinkle activity of T. hempricii assessed by collagenase inhibitory activities compared with the positive control.

- This scientific study support and suggest $T$. hempricii has the capability as an anti-wrinkle agent that is suitable for use in cosmetic products.

\section{ABOUT AUTHORS}

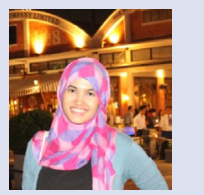

Kiki Zakiah., Kiki Zakiah Is a Pharmacy Technology student at Faculty of Pharmacy, Universitas Indonesia.

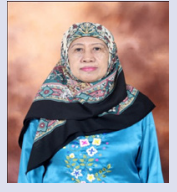

Effionora Anwar is a Professor at Department of Pharmacy Technology, Faculty of Pharmacy, Universitas Indonesia. She has many experienced in semisolid formulation from medicinal plants.

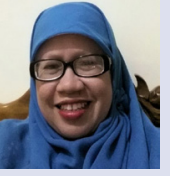

Tati Nurhayat Just got her Professorship on May, 2018 from The Faculty of Fisheries and Marine Sciences, Bogor Agricultural University - Indonesia. She has many experienced in enzymatic assay

Cite this article: Zakiah K, Anwar E, Nurhayati T. In-vitro Evaluation of Antioxidant Activity and Anti-collagenase Activity of Thalassia hempricii as a Potent Ingredients for Anti-Wrinkle Cosmetics. Pharmacog J. 2018;10(4):778-82. 